\title{
WAVE RUN-UP OBSERVATION AND 2DV NUMERICAL INVESTIGATION ON BEACHES PROTECTED BY STRUCTURES
}

Renata Archetti ${ }^{1}$ and Maria Gabriella Gaeta ${ }^{2}$

\begin{abstract}
The main parameter for the assessment of coastal vulnerability and sediment transport is the wave run-up on the beach, defining the limit of maximum flooding, but also hydrodynamic properties in the Swash Zone (SZ) are trivial for the comprehension of hydro-morphodynamic processes. Several studies have been carried out on the SZ but few literature is still available on the run-up and on SZ flows on beaches protected by Low Crested Structures (LCSs), where flow motion is driven by a combination of low frequency infra-gravity waves and incident waves. In presence of breakwaters, swash incident waves are transmitted through the structure. In the transmission area behind the structures, wave energy is shifted to higher frequencies with respect to the incident wave spectrum and in general its mean period considerably decreases with respect to the incident one. Collecting in situ run-up measurements during storms is essential to understand the SZ processes and properly calibrate their both empirical and numerical models but measuring extreme run-up is difficult, due to the severe sea conditions and due to unexpected nature of storms. The present paper present a numerical and experimental analysis of the wave run-up and of the flow properties on a beach: the study shows the different behavior of unprotected and protected beach, subjected to the same wave conditions. In particular the paper shows that submerged breakwaters reduce in general the run-up height, on the basis of the calibrated 2DV numerical simulations, under extreme wave conditions $\left(T_{R}>50\right.$ years), the effect of submerged breakwaters seems to be negligible on the run-up height. Moreover a preliminary empirical equation for run-up with protected beach is proposed
\end{abstract}

Keywords: run-up, video monitoring, numerical modeling, low crested structures, flooding hazard

\section{INTRODUCTION}

The determination of the risk of coastal inundation, defined as the flooding of coastal lands by ocean waters, has particular importance in many areas around the world. Generated by infrequent storms, severe coastal inundation is an event of relatively short duration but that can cause significant damage. The increase of the coastal water level above the astronomical tide during a storm is due to four distinct effects: barometric pressure, wind and wave setup, and wave run-up.

Traditionally, coastal flooding risks have been defined using an "event" based approach by which major storms are identified and extreme value analyses applied to derive the probabilities of extreme wave events. Subsequently, these have to be combined with similar extreme events of astronomical tide and storm surge levels using joint probabilities to derive the extremes of potential flood elevations.

Estimation of run-up is a crucial point in the mapping of vulnerability of coastal zones due to flooding. Low-lying areas in the coastal zone are vulnerable to flooding due to storm surge. The flooding episodes coming from the sea are principally due the effect of a storm surge, causing wave set up and wave run-up. These flooding scenarios together with the high human pressure on the coastal areas lead to coastal vulnerability.

The main impacts of these hazards on the coast turn into coastal erosion and the reduced width of beaches due to the increased sea levels and storm surges. Difficult decisions are required from those with responsibility for the management of coastal defences. Storm surge is the cause of wave overtopping which leads to flooding, of which the disastrous consequences are well known, but extreme overtopping events throw water over the crest with considerable velocities imposing serious hazards to both people and infrastructure. Indeed, these events can be extremely dangerous to people, cars and small buildings.

Stockdon et al. (2006) suggests that the $2 \%$ of exceedance level derived from the probability density functions of run-up time series is a valuable measure of inundation hazard during storms.

Collecting in situ data of run-up during storms becomes necessary for a proper calibration for both empirical and numerical models: measure extreme run-up is difficult, due to the severe sea conditions and to the unpredicted nature of storms.

In literature, several parametric formulae are available to estimate run-up and extreme run-up (runup exceeded $2 \%$, hereinafter $\mathrm{R}_{2} \%$ ), they are manly based on laboratory experiments with a beach cross section with constant steepness (Hunt 1959, Battjes 1974 and recently Soldini et al. 2012, Sancho et al. 2001, Bellotti et al., 2003) or field studies (Holman and Sallanger 1985, Nielsen and Hanslow 1991, Bryan et al. 2008, Vousdoukas et al. 2009). Recently Stockdon et al. (2006) proposes a universal empirical formula aimed to estimate $\mathrm{R}_{2} \%$ from offshore conditions.

\footnotetext{
${ }^{1}$ University of Bologna, DICAM, Viale Risorgimento, 2, BOLOGNA 40136 Italy. renata.archetti@unibo.it.

${ }^{2}$ University of Bologna, CIRI Fluidodynamics, Via del Lazzaretto 15/5, BOLOGNA 40134 Italy. g.gaeta@unibo.it.
} 
They considered several beaches exposed to ocean and long fetches. Structures parallel to the coast are designed in order to reduce the coastal erosion, but in several conditions they could be responsible for the increasing in wave run-up, due to the pilling up caused by the same structures. Studies and observations of run-up in presence of parallel structures are rare. Recently Hur et al. (2012) analyzed by means of $3 \mathrm{D}$ numerical simulations the characteristics of wave run-up height at shoreline with various arrangements of dual-submerged breakwaters. They found that for the considered configuration the wave run-up level at the shoreline behind the submerged breakwater is generally larger than that behind the open inlet.

The aim of the present paper is twofold: the numerical and experimental analysis of the wave runup are performed on both a natural and a protected beach, subjected to the same wave conditions.

The paper is organized in the following parts: in the first section the study site and the field data are described; then the numerical model selected for the simulation is presented. For both the natural beach and the beach protected by the structure, the model set up and the validation are shown in details.

In Section 3, a comparison among results of numerical and empirical formulation is performed and, finally, the analysis on the run-up on protected and unprotected beaches under extreme waves is presented and discussed.

\section{STUDY SITE DESCRIPTION AND FIELD DATA}

The present study focuses on the Emilia Romagna coast, located in the Northern Adriatic sea. The coast of the region is a sandy dissipative beach and part of the land is a low land, at a level below the mean sea. It is clear how the flooding risk is a major issue in this region. For the importance of the topic, this area has been a study site during several Italian and international research projects. The wave climate is permanently monitored by two gauges: the wave buoy managed by ARPA SIM (http://www.arpa.emr.it/sim/mare/boa) and the tidal gauge sited offshore Cesenatico.

Experiments have been carried out at a specific location of the study site, between two river mouths, River Bevano at the south and River Fiumi Uniti at the north. We focus on this location because it is representative for the entire coastal region.

The Northern part, Lido di Dante, is protected by a system of structures. The Southern adjacent part is natural and the land in the back of the beach is protected by a system of dunes. So this is a perfect, suitable site in order to compare the different effects of storms and in terms of wave run-up on a beach. In case of beach protected by structures and in case of natural beach, which are subject to the same wave and meteorological conditions. The northern part, Lido di Dante, has been a study site during several projects (i.e. DELOS and CoastView projects), while the southern part is characterized by a natural dissipative beach protected by dunes; an available DEM shows the height of the dune and in particular the most critical part of the areaa with only 1.3 meter level above the sea and where we can expect a greater risk and hazard due to flooding during storms. The extension of this part is approximately 1 kilometer and the extension of the southern part is approximately 2.5 kilometers.

Lido di Dante is protected by a system of parallel structures, which are located 180 meters far from the beach, and three groins (Lamberti et al. 2005). 


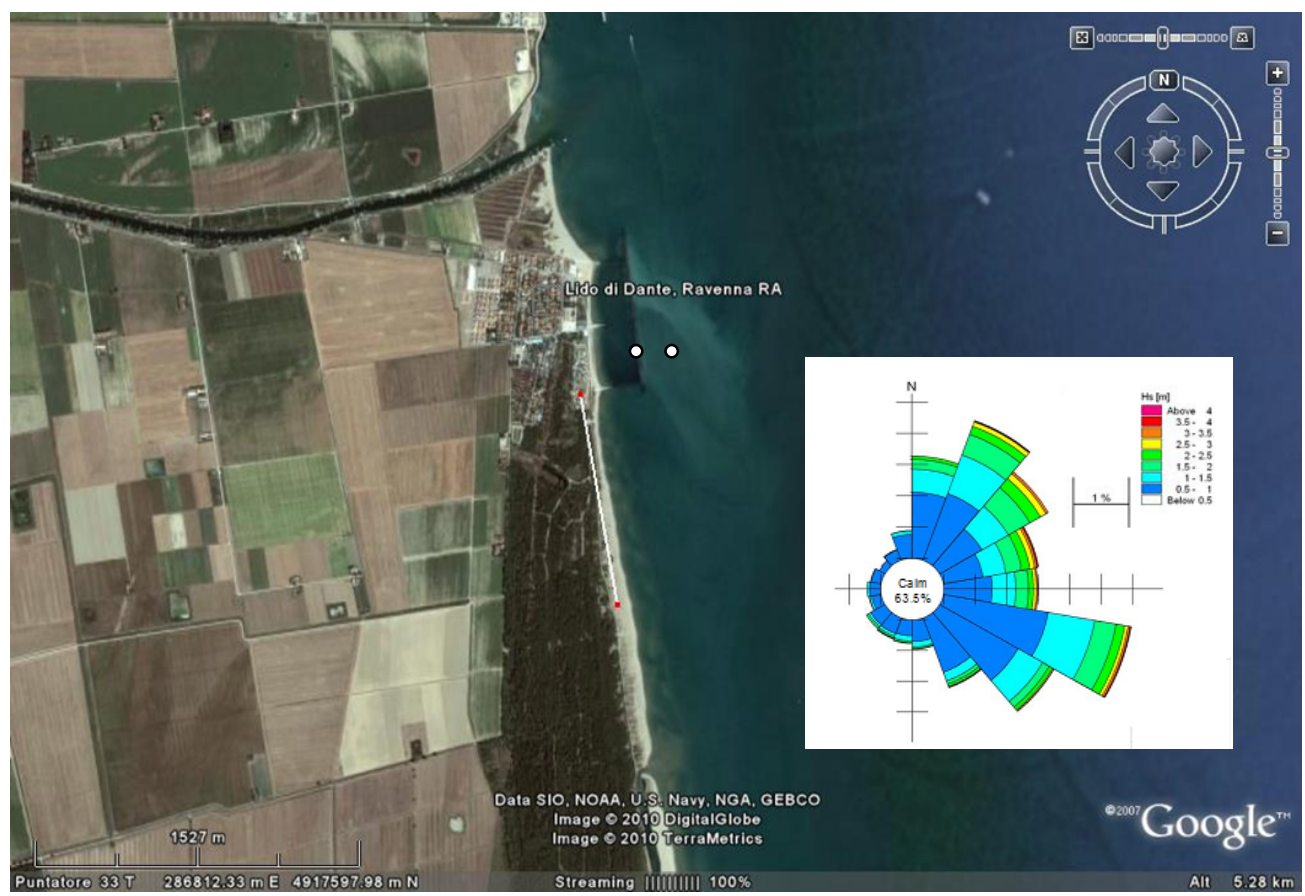

Figure 1. Aerial view of Lido di Dante. The white bulls represent the location of the ADCPs during the field campaigns. On the same image, the offshore wave climate is plotted.

\section{Field data}

Detailed data and information on the site are available thanks to several field campaigns planned in the last 10 years.

In the period 2003 - 2008, four intensive field campaigns were carried out aimed to measure waves and currents inside and outside the protected area, the set up or piling up (difference between sea water level on shore and offshore the pparallel breakwater) and the wave transmission.

Two ADCPs RDI Workhorse Sentinel self contained $1200 \mathrm{KHz}$, suitable for shallow water measurements, were installed at the sea bottom during 4 exhaustive hydrodynamic surveys: the first one at a depth of $3.5 \mathrm{~m}, 20 \mathrm{~m}$ onshore the LCS gap, and the second one offshore the low crested structures (the position of the ADCPs is shown in Archetti and Lamberti 2006).

The ADCPs were programmed in order to measure directional waves every hour and velocity components along the vertical profiles, the deepest cell was placed $1 \mathrm{~m}$ from the bottom. The dimension of the cells was $0.35 \mathrm{~m}$. In the same time wave data were collected by the Wave Buoy in Cesenatico and sea water levels were collected by the tidal gauge placed in the Ravenna harbour (Porto Corsini).

At the same time, video images of the site were collected by the ARGUS station (Archetti, 2009). Besides the conventional images produced by the ARGUS (snapshot, timex and variance), the system is able to produce timestacks images, that are images in which the intensity of an array of pixels is plotted against time. Timestacks used in the research were located perpendicular to the studied beach.

Timestacks were collected every hour for a duration of 7 minutes at $2 \mathrm{~Hz}$ frequency.

The video monitoring station installed in 2003 at Lido di Dante is a 3rd generation ARGUS station (Holman and Stanley 2007). 

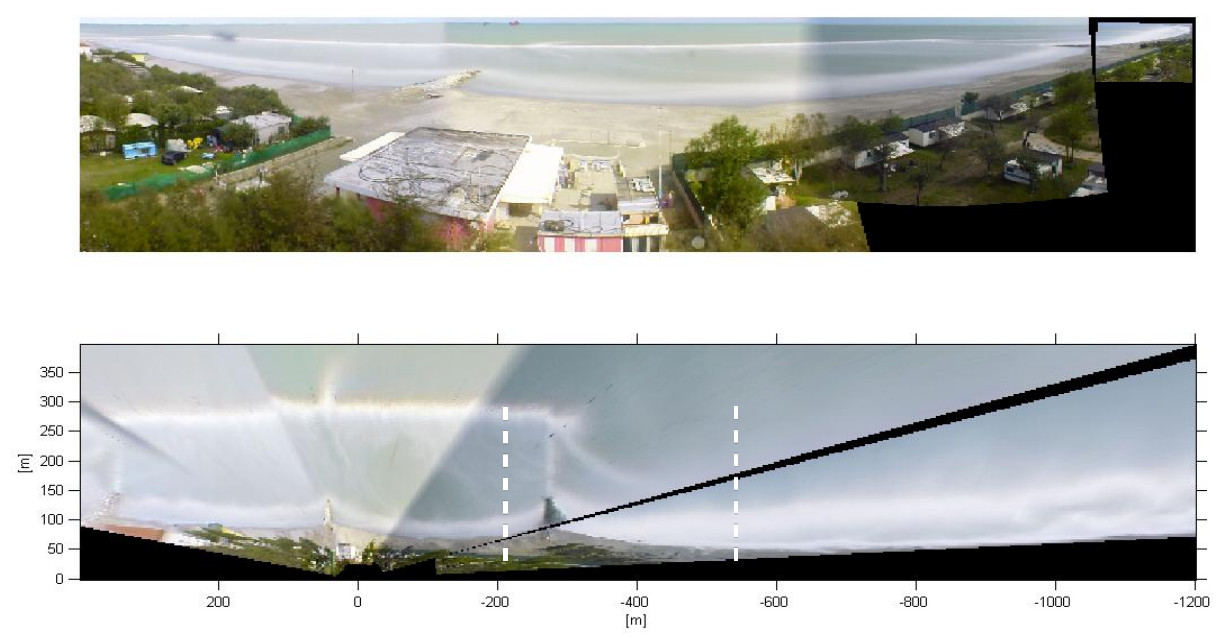

Figure 2. Plan view of Lido di Dante from ARGUS. Timestacks locations are outlined perpendicular to the beach (white dashed lines).

In this case, timestacks are able to show the run-up of the wave on the beach in the time. These optical instruments are equivalent to run-up gauges located on the beach.

An example of the plan view in Lido di Dante is presented in Figure 2, where the timestacks have been simultaneously collected at the two cross sections (dotted lines). One of the collected timestacks is shown, as example, in Figure 3, where the run-up extension on the beach and the peaks of the waves are clearly detected.

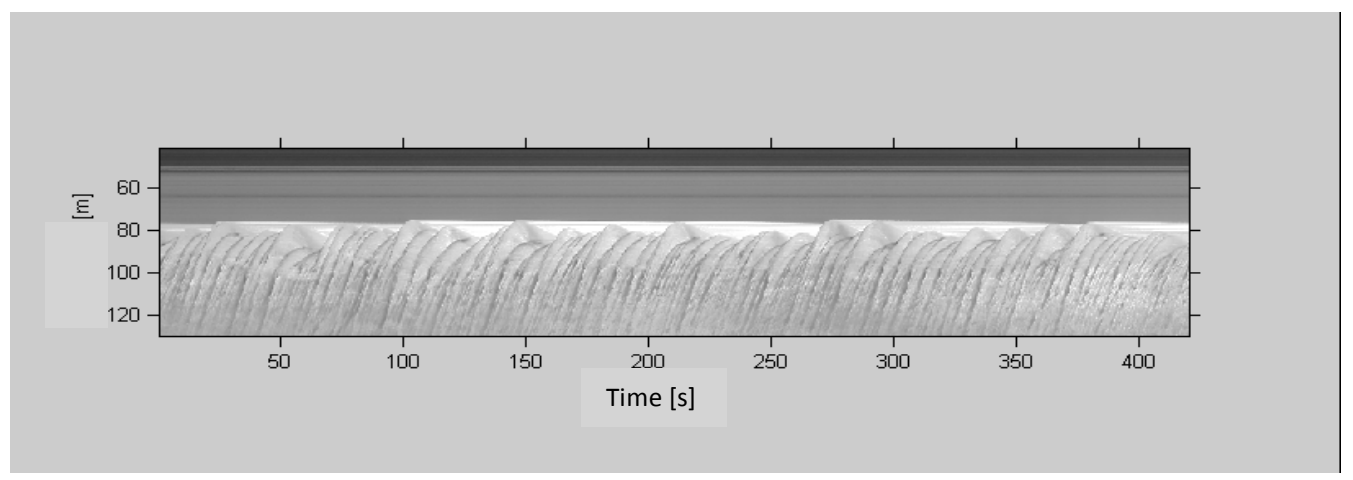

Figure 3. Example of timestacks collected by the ARGUS station in Lido di Dante.

\section{Run-up measurement: the methodology}

The run-up position is automatically detected on timestacks. The procedure is articulated in the following steps:

\section{Selection of good quality run-up timestacks collected during storms}

A total of 43 timestacks collected during storms and of good quality has been selected in the time spam between $1^{\text {st }}$ Sept 2007 and 31 March 2008, because a detailed multi-beam bathymetry performed in November 2007 is available.

\section{Detection of wave run-up extension time series}

In order to automatically detect the run-up extension on the beach, a proper procedure is developed for this work. This is based on the definition of a threshold of intensity pixel values: higher values are correlated to the sea, and lower values are correlated to the beach. 


\section{Estimation of the wave run-up height: comparison of the bathymetry with intertidal beach bathymetry.}

It is worth notice that in reality from this type of images we are able to detect the run-up extension on the beach, but not the run-up height. So with the aim to estimate the run-up height, which is the requested parameter in the estimation of the flooding hazard and vulnerability of the coast, it is necessary to transpose the run-up extension on the beach to the run-up height. This is an easy algorithm that correlates the extension to the height through the beach steepness. The main cause of error is that the beach steepness and the beach shoreline position are very dynamic. Previous works have quantified the evolution of the intertidal beach shape in Lido di Dante and the shoreline position (Archetti and Romagnoli, 2011) during storms. So in order to have a measure on the beach steepness and shoreline beach position at the beginning of the analyzed timestack, a sort of recalibration on the position of the sea water level and of the steepness of the beach is performed by detecting the intertidal beach bathymetry through a "video-based" algorithm. This is possible because in the Adriatic Sea the tidal exclusion is not very high but is sufficient in order to detect the intertidal beach bathymetry (i.e. the tidal vertical range is approximately $\pm 40 \mathrm{~cm}$ ). This means that we are able to obtain more or less every two weeks the survey of the intertidal beach (through the availability of the sea water level by the tidal gauge located very close) and interpolate the shoreline position. The reconstruction of the crossshore profile position is so possible before each timestack measurement. Details on the methodology and its application are presented in Aarninkhof (1999) and in Archetti (2009).

So just to summarize, before the beginning of the storm, the position of the shoreline, the steepness of the beach are detected and the cross-shore profile of the beach is reconstructed at the location of the 2 timestacks (see Figure 2) at the natural and protected beaches respectively.

\section{Detection of the run-up peaks and their statistics}

Once the run-up height is available, the wave peaks on the beach have been selected and their distribution and statistics are estimated, in particular the $\mathrm{R}_{2 \%}$ and $\mathrm{R}_{\text {mean }}$ values.

\section{Run-up simulation: the model set-up and validation}

The used numerical model originally developed by Lin and Liu (1998) solves the 2DV Reynolds Average Navier-Stokes (RANS) equations and the k- $\varepsilon$ closure (Launder et al. 1972) is adopted to model the Reynolds stress tensor. The implemented filtration law to simulate flows inside and around the rubble mound structures follows the Forchheimer expression, also accounting for non-linear effects. Torres-Freyermuth et al. (2006) and Clementi et al. (2007) validated the model for the simulations of wave interaction with LCSs, finding a good agreement to field and experimental data, especially in terms wave shoaling and run up.

More details on the model can be found in Lin and Liu (1998), Lara et al. (2006) and Gaeta et al. (2009).

Two surveyed cross sections located at the center of the natural and the protected beaches at Lido di Dante are chosen and implemented in the numerical domain of the model, with dimensions equal to $350 \mathrm{~m} \times 8 \mathrm{~m}$. A grid sensitivity analysis has been firstly carried out in order to choose cell dimensions and distribution that slightly influence the computed results.

Figure 4 shows the numerical domain for the natural (a) and protected beach (b), where the implemented breakwater is characterized by the geometrical dimensions as reported in Lamberti et al. (2005) and by the filtration coefficients as largely tested and validated in Clementi et al. (2007) for similar LCSs. 

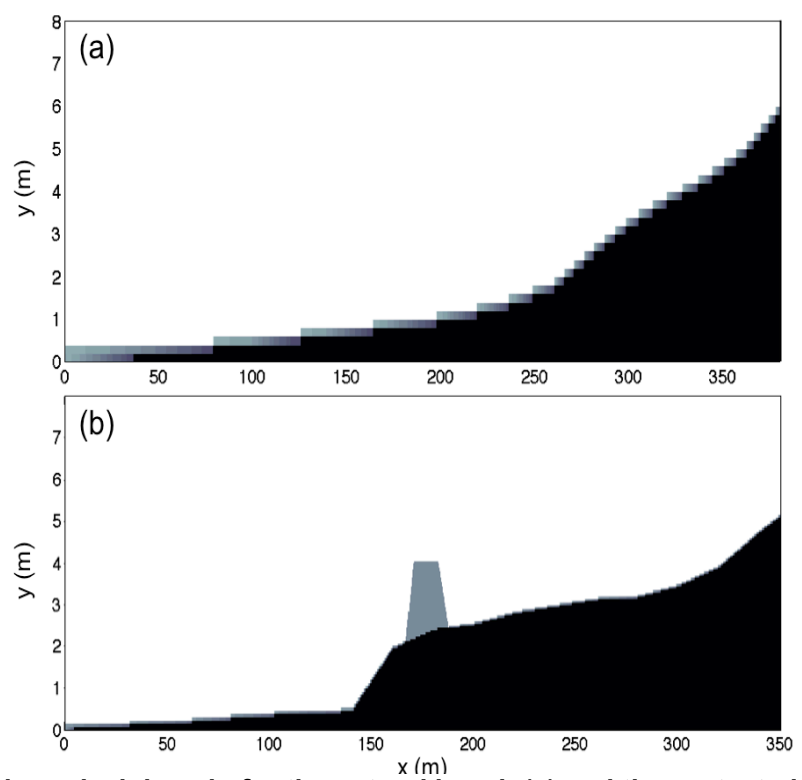

Figure 4. Numerical domain for the natural beach (a) and the protected beach (b).

In the present model, the wave generation occurs at the left boundary of the numerical domain, imposing free surface elevation and velocity profile according to linear wave theory using the Jonswap spectrum $(\gamma=3.3)$, while no-slip and Neumann conditions are imposed at the bottom.

In the calibration and validation tests, the wave attacks reported in Table 1 are reproduced simulating a one-hour storm and propagating both over the natural and the protected beaches.

\begin{tabular}{|c|c|c|c|c|c|}
\hline Test name & Date & $\begin{array}{c}d \\
\text { (m) }\end{array}$ & $\begin{array}{l}\Delta \mathrm{h} \\
(\mathrm{m})\end{array}$ & $\begin{array}{c}\mathrm{H}_{\mathrm{s}} \\
(\mathrm{m})\end{array}$ & $\begin{array}{l}\mathrm{T}_{\mathrm{p}} \\
\text { (s) }\end{array}$ \\
\hline W1 & 221020070650 & 4.0 & 0.45 & 2.75 & 7.69 \\
\hline W2 & $22102007 \quad 1050$ & 4.0 & 0.29 & 2.41 & 7.14 \\
\hline W3 & $17112007 \_1250$ & 4.0 & 0.17 & 1.68 & 6.67 \\
\hline W4 & 23112007 1150 & 4.0 & 0.14 & 1.24 & 8.33 \\
\hline
\end{tabular}

The computed results are compared to the run-up data collected by means of the video monitoring technique as described in the previous section.

A comparison in terms of statistical values for the run-up is performed between simulation results and measurements. Figure 5 presents the results for wave W1 propagating along the natural beach. The solid black line shows the numerical evolution of the run-up in time; the dotted lines and the pointed lines represent the $R_{2}$ and the $R_{\text {mean }}$ values respectively, for numerical model (in blue) and for observations (in red).

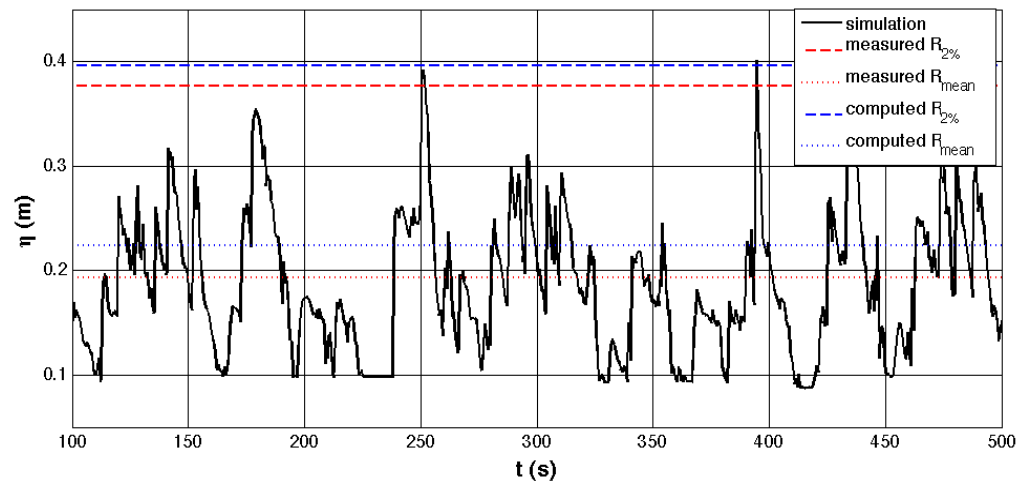

Figure 5. Wave W1 on the natural beach: comparison between measured (red line) and computed (blue line) $\mathbf{R}_{\mathbf{2} \%}$ and $\mathbf{R}_{\text {mean }}$ values. 
For all the tests the agreement is fairly good: the model seems to be able to satisfactorily predict the wave propagation and flow patterns across the surf zone.

For the protected beach, the presence of gaps between the LCSs complicated the reproduction by 2DV model. However, two additional parameters for the model calibration are available: the piling-up value, (measured difference between the sea water level onshore and offshore the breakwater) and the transmitted wave through the structures.

Figure 6 shows the computed run-up against the observations: the agreement is fairly good.

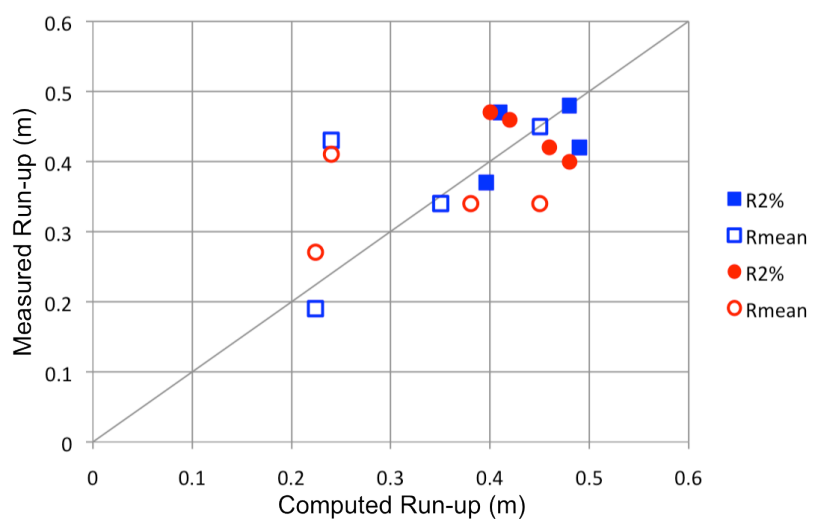

Figure 6. Comparison between measured and computed run-up for the natural (blue symbols) and the protected (red symbols) beaches.

\section{Observations vs. empirical estimation}

The first data analysis consisted in the comparison between the measured run-up on the natural beach estimated by the timestacks analysis and the empirical run-up obtained by applying the most common formulae in literature by Stockdon et al. (2006). The comparison is reported in terms of scatter plot in Figure 7: the observed values show a good agreement with the estimated ones.

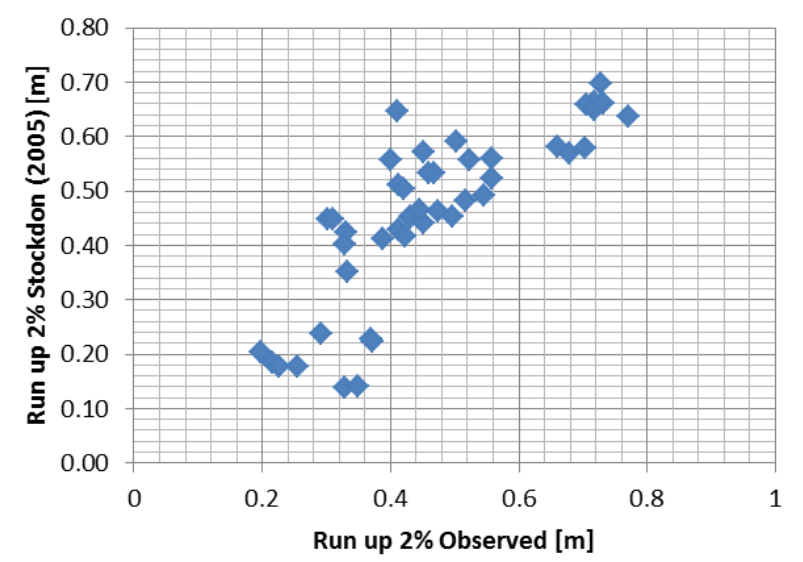

Figure 7. Observed vs empirical by Stockdon et al. (2006) formula R2\%.

Wave run-up in presence of structures has been measured at the present study site applying the same methodology used for the natural beaches. In order to compare and to parameterize the process, under the approach used by Stockdon et al. (2006) for natural beaches, we have considered the value for $\mathrm{R}_{2 \%}$ as the sum of two main contributions: the excursion of the infragravity waves on the swash and the mean of the sea level.

The first contribution is correlated to the wave conditions at the site, i.e. the transmitted waves over the parallel structures. In order to parameterize transmitted waves in presence of a LCS in Lido di Dante, our measurements of transmitted waves have been compared to the most well-known equations available in literature for the estimation of transmitted waves in presence of structures (van der Meer and Daemen 1994, D'Angremont et al. 1996, van der Meer et al. 2005, Bezzi 2011). Generally, the 
available empirical equations are based on data acquired during laboratory experiments, while for this case field data are used, so some scale effects can arise by this comparison.

An example of significant wave height onshore and offshore is presented Figure 8, where the green line represents the wave height $\mathrm{H}_{\mathrm{s}, \mathrm{i}}$, as measured offshore the parallel structures. The light blue line shows the transmitted wave height $\mathrm{H}_{\mathrm{s}, \mathrm{t}}$, as measured by the ADCP onshore the breakwater, while red, black and dark blue lines report the transmitted wave height, as estimated by empirical equations in literature as presented in the figure legend.

The best agreement with the observations is reached by means of the equation proposed by van der Meer et al. (2005), used hereafter in the present study.

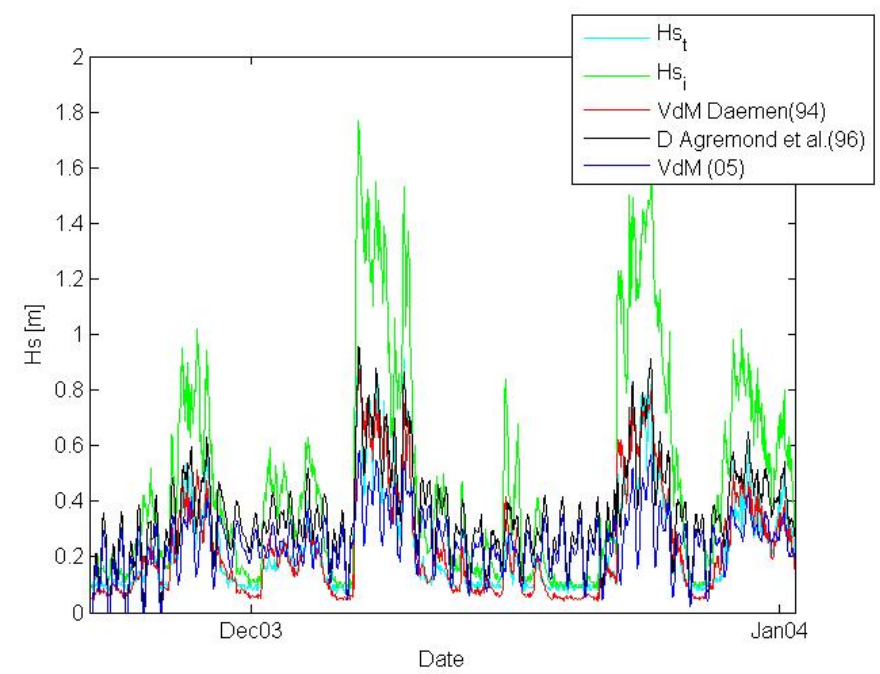

Figure 8. Measurement of wave height $H_{s}$ by ADCPs: green and light blue lines for offshore and onshore locations respectively, The wave transmission is estimated by empirical expressions (in red, black and blue lines).

The wave setup or piling-up $\Delta \eta$ (i.e. the vertical difference between the seawater level inside and outside the protected area ) is presented in Figure 9 during the first ADCP field campaign.
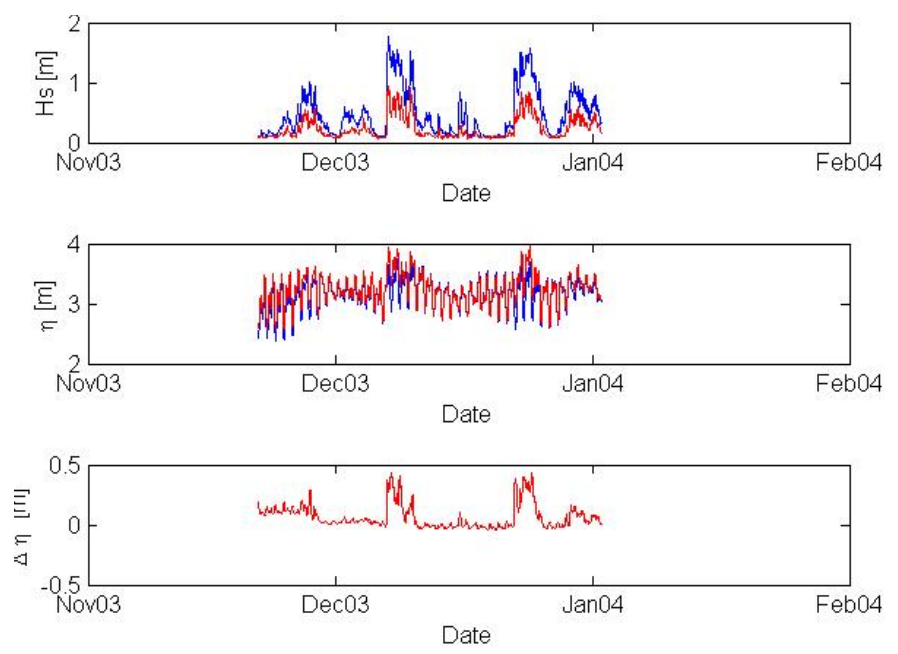

Figure 9. Measurement of wave height $H_{s}$ and wave piling-up $\Delta \eta$ during the 1 st field campaign at Lido di Dante.

In figure 9, the value for $\Delta \eta$ increases during storms and decreases with freeboard (the distance from the top of the structure from the seawater level $\mathrm{R}_{\mathrm{c}}$ ). Based on data collected during the four field campaigns, a calibration on the existing piling up equation by Loveless (1998) is obtained as a function of the offshore significant wave height $\mathrm{H}_{\mathrm{s}}$ and of the structure freeboard $\mathrm{R}_{\mathrm{c}}$ :, as: 


$$
\frac{\Delta \eta}{H s}=0.34+0.50 \frac{R c}{H s}
$$

Merging the two described contributions and analyzing the variability of the run-up $\mathrm{R}_{2 \%}$ in presence of parallel structures with the values of $\mathrm{H}_{\mathrm{s}, \mathrm{t}}$ and $\Delta \eta$, the following expression is found:

$$
\mathrm{R}_{2 \%}=\mathrm{a} \cdot \mathrm{H}_{\mathrm{s}, \mathrm{i}}+\mathrm{b} \cdot \mathrm{R}_{\mathrm{c}}+\mathrm{c} \cdot \beta_{\mathrm{r}}\left(\mathrm{k}_{\mathrm{t}} \mathrm{H}_{\mathrm{s}, \mathrm{i}}\right)^{1 / 2} \mathrm{~T}
$$

where $\mathrm{k}_{\mathrm{t}}$ is the wave transmission coefficient and $\beta_{\mathrm{f}}$ is the beach steepness.

The calibration of the Eq. (2) with the $\mathrm{R}_{2} \%$ field data (Figure 10) yields to the following values for the coefficients $\mathrm{a}=0.34, \mathrm{~b}=0.50$ and $\mathrm{c}=1$.

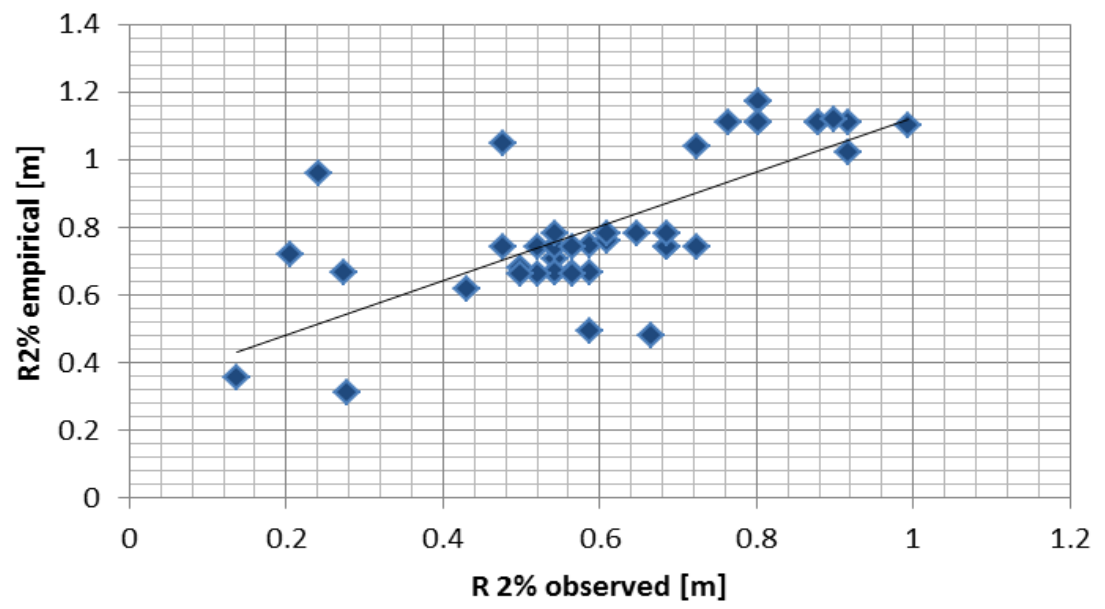

Figure 10. Comparison between observed and empirical $R_{2} \%$ from Eq. (2) on the beach protected by LCSs.

The result seems quite promising. We are confident that future research based on more analyses will give more results on this topic. So at the end of this part it was possible to give an empirical description of the run-up on beach protected by structure. More data will be useful to check if this empirical equation can be used or calibrated in other field conditions. The authors would like to point out that during this analysis, in the estimation of the piling up, for simplicity we didn't take into account the phenomenon of outflowing of the water through the gap of the structure. In reality in this case, there is a very narrow gap compared to the dimension of the structures. The consequence of this hypothesis can be an overestimation of the piling up and an overestimation of the $\mathrm{R}_{2} \%$ on the beach.

\section{Comparison between the two beaches configuration under extreme waves}

Finally, in this last section, the run-up on beaches protected by the structures is compared with the run-up on the natural beaches, by means of measurements and numerical results.

Observations based on the timestacks are presented in Figure 11: in blue line the observed $\mathrm{R}_{2 \%}$ on a natural beach and in red line on the protected beach. The higher values for $\mathrm{R}_{2 \%}$ are found on the natural beaches, as expected. During the run-up field tests several storms were experienced, the wave height $\mathrm{H}_{\mathrm{s}}$ reached the value of $2.75 \mathrm{~m}$ and the sea water level $0.45 \mathrm{~m}$, These conditions have approximately 1 year return period (Lamberti et al. 2012, Masina, 2011). 


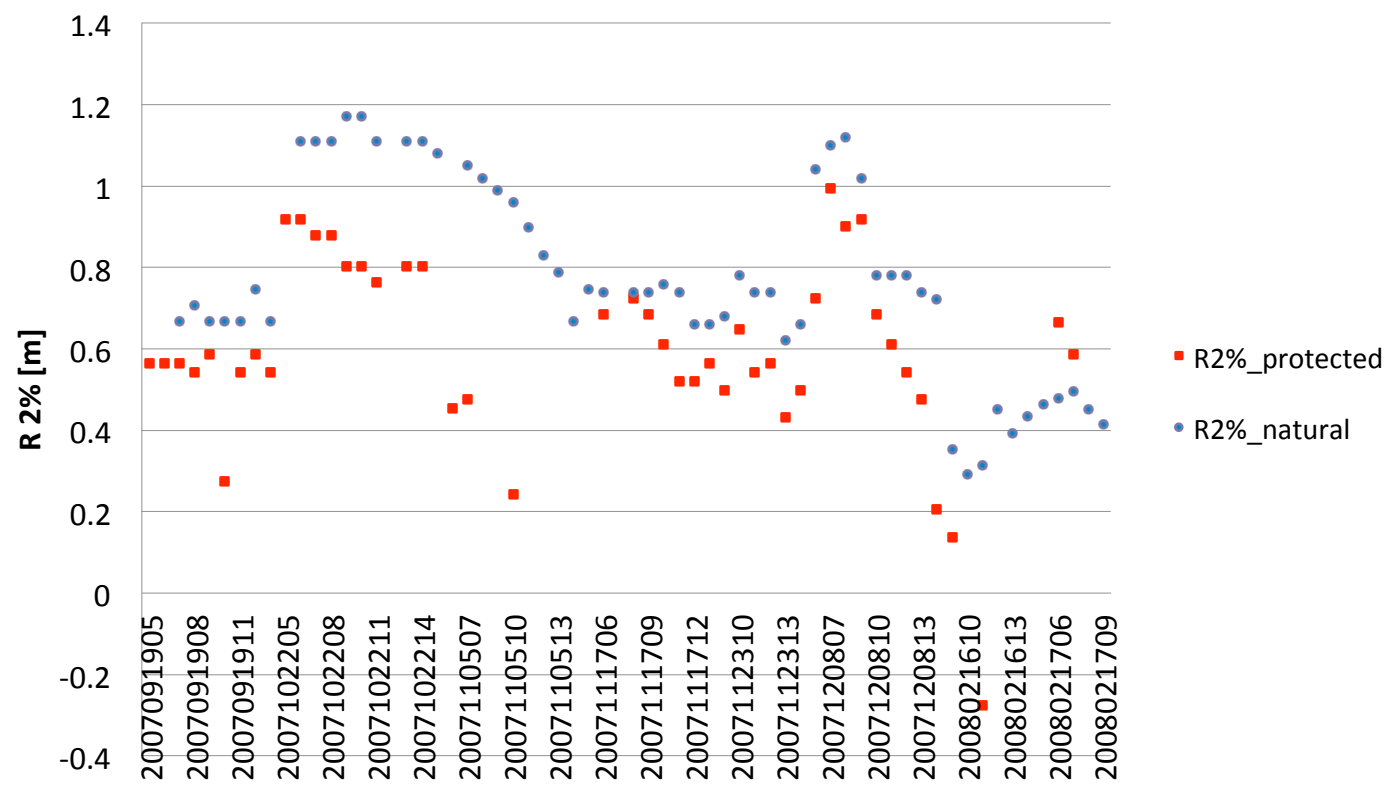

Figure 10. Measured R2\% on natural beach (blue symbols) and on protected beach (red symbols).

In order to analyze the different behaviors during extreme events, the conditions listed in Table 3 , combination of extreme $\mathrm{H}_{\mathrm{s}}$ and swl, have been simulated by means of the numerical model, so it was possible to estimate if the run-up difference for protected beach still verify during extreme events.

\begin{tabular}{|c|c|c|c|c|c|}
\hline Test name & $\begin{array}{l}T_{R} \\
(y) \\
\end{array}$ & $\begin{array}{l}\text { swl } \\
\text { (m) }\end{array}$ & $\begin{array}{l}\mathrm{H}_{\mathrm{s}, 0} \\
(\mathrm{~m})\end{array}$ & $\begin{array}{l}\mathrm{H}_{\mathrm{s}, \mathrm{i}} \\
(\mathrm{m})\end{array}$ & $\begin{array}{l}T_{p} \\
(s)\end{array}$ \\
\hline E1 & 10 & 0.93 & 3.91 & 3.58 & 9.1 \\
\hline E2 & 20 & 1.05 & 4.3 & 4.02 & 9.3 \\
\hline E3 & 50 & 1.09 & 4.8 & 4.07 & 9.5 \\
\hline E4 & 100 & 1.15 & 5.1 & 4.12 & 9.6 \\
\hline
\end{tabular}

For all the simulations, results are summarized in Table 4. Conditions are expressed in terms of freeboard, which changes with the seawater level exclusion, offshore significant wave height, wave peak period and wave length. On the basis of the computed results, it seems that when extreme events occur, with a return period greater than 50 years, the wave run-up is approximately the same for the whole beach, no matter if protected or not.

\begin{tabular}{|c|c|c|c|c|c|c|c|c|}
\hline & & COND & TION & & $\mathrm{NA}$ & RAL & PROT & CTED \\
\hline Test & \begin{tabular}{|c|}
$R_{c}$ \\
$(m)$ \\
\end{tabular} & $\begin{array}{c}\mathrm{H}_{\mathrm{s}} \\
(\mathrm{m}) \\
\end{array}$ & $\begin{array}{c}T_{p} \\
(\mathrm{~s}) \\
\end{array}$ & $\begin{array}{c}\mathrm{L} \\
(\mathrm{m})\end{array}$ & $\begin{array}{l}R_{\text {mean }} \\
(\mathrm{m})\end{array}$ & $\begin{array}{l}\mathrm{R}_{2 \%} \\
(\mathrm{~m}) \\
\end{array}$ & $\begin{array}{l}R_{\text {mean }} \\
(\mathrm{m}) \\
\end{array}$ & $\begin{array}{l}\mathrm{R}_{2 \%} \\
(\mathrm{~m}) \\
\end{array}$ \\
\hline W1 & 0.45 & 2.75 & 7.69 & 92.25 & 0.22 & 0.39 & 0.14 & 0.35 \\
\hline W1 & 0.00 & 2.75 & 7.69 & 92.25 & 0.18 & 0.37 & 0.11 & 0.28 \\
\hline E1 & 0.93 & 3.9 & 9.1 & 129.18 & 0.38 & 0.78 & 0.37 & 0.76 \\
\hline E2 & 1.05 & 4.3 & 9.3 & 134.92 & 0.38 & 0.82 & 0.35 & 0.80 \\
\hline E3 & 1.09 & 4.8 & 9.5 & 140.79 & 0.37 & 0.90 & 0.46 & 0.84 \\
\hline E4 & 1.15 & 5.1 & 9.6 & 144.35 & 0.77 & 1.04 & 0.68 & 0.92 \\
\hline
\end{tabular}

\section{Discussion on future works and discussion}

We are confident that future research based on further analysis on the study site will give interesting results on this topic. The present study results could be summarized as follows. 
- The general equation developed by Stockdon et al. (2006) well reproduces the $R_{2 \%}$ at the natural beach at the study site coast.

- Submerged breakwaters reduce in general the run-up height, confirming results by Hur et al. (2012).

- On the basis of the calibrated 2DV numerical simulations, under extreme wave conditions $\left(\mathrm{T}_{\mathrm{R}}>50\right.$ years), the effect of submerged breakwaters seems to be negligible on the run-up height.

- A preliminary empirical equation for run-up with protected beach is proposed. A wider range of runup data will be useful to further validate this empirical equation or calibrate it in other field conditions.

- More research needed on wave spectra transformation behind the structures.

\section{ACKNOWLEDGMENTS}

The research was supported by the project PRIN 2008YNPNT9 "Tools for the assessment of coastal zone vulnerability related to the foreseen climate change" financed by the Italian Ministry of University and Research (MIUR).

\section{REFERENCES}

Archetti, R., and A. Lamberti. 2006. Study of hydrodynamic induced by low crested structures through image processing. Proc. of the $30^{\text {th }}$ International Conference on Coastal Engineering, ASCE, 5021 -5033 .

Archetti R. 2009. Study of the evolution of a beach protected by low crested structures using video monitoring. Journal of Coastal Research. Vol 25(4). Pp 884 - 899. Issn 1551-5036.

Archetti, R. and Romagnoli, C. 2011, Analysis of the effects of different storm events on shoreline dynamics of an artificially embayed beach. Earth Surface Processes and Landforms. doi: 10.1002/esp.2162.

Aarninkhof, S.G.J And Roelvink, J.A., 1999, Argus-based monitoring of intertial beach morphodimanics. Proc. Coastal sediment 1999: 2429-2444.

Bellotti G., Archetti, R.,e Bocchini, M. 2003. Experimental validation and characterization of mean swash zone boundary conditions $J$. Geophys. Res.Vol.108,No.C8,3250 - 3266.

Bezzi E. 2011. Effetti delle opere di protezione costiera:la trasmissione e l'evoluzione del litorale nei casi studio di Lido di Dante e Igea Marina. Master thesis Corso di laurea magistrale in Ingegneria dei sistemi edilizi e urbani. University of Bologna.

Clementi E., M. G. Gaeta, and A. Lamberti. 2007. Filtration through low crested structures in 2D experimental and numerical investigations, Proc. of Coastal Structures Conference, 1, 927-938.

AA.VV. Coastal Engineering Vol. 52, Issues 10-11, 815-1126 Special Issue on Low Crested Structures and the Environment.

d'Angremond K., J.W. van der Meer, R.J. De Jong. 1996. Wave transmission at low crested structures. Proc. 25th Int. Conf. on Coastal Engineering, ASCE (1996), pp. 3305-3318.

Gaeta, M. G., A. Lamberti, and P. L.-F. Liu. 2009. A two-phase numerical model for incompressible fluids: air influence in wave propagation and applications, Proc. of the $31^{\text {st }}$ International Conference on Coastal Engineering, ASCE, 144-156.

Holman RA, Stanley J. 2007. The history, capabilities and future of Argus. Coastal Engineering 54(67): 477-491.

Holman, R.A., A.H. Jr. Sallenger, T.C. Lippmann, and J. Haines. 1993. The application of video image processing to the study of nearshore processes, Oceanography, 6 (3), 78-85.

Hunt, I.A. 1959. Design of Seawalls and Breakwaters, Journal of the Waterways and Harbors Division, Proc. of the American Society of Civil Engineers, 85 (WW3), 123-152.

Hur, D.-S., W.-D. Lee, and W.-C. Cho. 2012. Characteristics of wave run-up height on a sandy beach behind dual-submerged breakwaters, Ocean Engineering, 45, 38-55.

Johnson, B.L. and C.A. Johnston. 1995. Relationship of Lithology and Geomorphology to Erosion of the western Lake Superior Coast, J. of Great Lakes Research, 21(1), 3-16.

Kroon, A., S.G.J. Aarninkhof, R. Archetti, C. Armaroli, M. Gonzalez, S. Medri, A. Osorio, T. Aagaard, M. A. Davidson, R. A. Holman, and R. Spanhoff. 2007. Application of remote sensing video systems for coastline management problems, Coastal Engineering, 54 (6), 493-505.

Lamberti, A., R. Archetti, M. Kramer, D. Paphitis, C. Mosso and M. Di Risio. 2005. European experience of low crested structures for coastal management, Coastal Engineering, 52, 841-866. 
Lamberti A., M. Masina, and R. Archetti. 2012. Investigating dependence in the main sea state parameters with copula approach. Geophysical Research Abstracts. Vol. 14, EGU2012-1160, 2012. EGU General Assembly 2012.

Lara, J. L., N. Garcia, and I. J. Losada. 2006. RANS modelling applied to random wave interaction with submerged permeable structures, Coastal Engineering, 53, 395-417.

Launder, B. E., A. Morse, W. Rodi, and D. B. Spalding. 1972. Prediction of free shear flows: a comparison of the performance of six turbulence models, Free Shear Flow, 361-426.

Lin, P., and P. L.-F. Liu. 1998. A numerical study of breaking waves in the surf zone, Journal of Fluid Mechanics, 359, 239-264.

Mase, H. 1989. Random Wave Run-up Height on Gentle Slopes, Journal of Waterway, Port, Coastal, and Ocean Engineering, 115 (5), 649-661.

Masina M, 2011. Risposta morfologica della spiaggia compresa tra Lido di Dante e Lido di Classe ad eventi di mareggiata. PhD Thesis. Ferrara University.

Mickelson, D.M., T. B. Edil, and D. E. Guy. 2004. Erosion of coastal bluff in the Great Lakes, U.S. Geological Survey Professional Paper 1693, 107-123.

Nielsen, P., and D. J. Hanslow. 1991. Wave Run-up Distributions on Natural Beaches, Journal of Coastal Research, 7 (4), 1139-1152.

Platt, R. H. 1994. Evolution of coastal hazards policies in the United-States, Coastal Management, 22 (3), 268-284.

Sancho, F., Mendes, P.A., Carmo, J.A., Neves, M.G., Tomasicchio, G.R., Archetti, R., Damiani, L., Mossa, M., Rinaldi, A., Gironella, X., S-Arcilla, A. 2001. Wave hydrodynamics over a barred beach. Proc. of the IV Int. Symposium on Ocean Wave Measurement and Analysis. Vol.2, 2001, pp. 1170-1179.

Stockdon, H. F., R. A. Holman, P. A. Howd, and A. H. Sallenger Jr. 2006. Empirical parameterization of setup, swash, and run-up, Coastal Engineering, 53, 573-588.

Soldini, L., M. Antuono, and M. Brocchini. 2012. Numerical modeling of the influence of the beach profile on the wave run-up, J. of Waterway, Port, Coastal and Ocean Engineering, In press.

Torres-Freyermuth, A., I. J. Losada, and J. L. Lara. 2006. Modeling of surf zone processes on a natural beach using Reynolds-Averaged Navier-Stokes equations, Journal of Geophysical Research, 112, C09014, doi:10.1029/2006JC004050.

Van der Meer J.W and I.F.R. Daemen. 1994. Stability and wave transmission at low crested rubblemound structures. Journal of Waterway, Port, Coastal, and Ocean Engineering, 1 (1994), pp. 119.

Van der Meer 2005 J.W., R. Briganti, B. Zanuttigh, W. Baoxing. 2005. Wave transmission at low crested structures. Coastal Engineering, 52 (10) (2005), pp. 915-929. 